\section{ОСОБЛИВОСТІ ФОРМУВАННЯ ОРГАНІЗАЦЙНОЇ МОДЕЛІ ТЕРИТОРІАЛЬНИХ СТРУКТУР}

\section{FEATURES OF FORMATION OF ORGANIZATIONAL MODEL OF TERRITORIAL STRUCTURES}

\author{
ПОПОВА О. Ю., \\ доктор економічних наук, \\ професор, завідувач кафедри \\ управління і фінансової- \\ економічної безпеки, \\ ВАСИЛИШИНА Л. М., \\ старший викладач, \\ Донецький національний \\ технічний університет
}

\author{
POPOVA O., \\ Doctor of Science in Economics, \\ Professor, Head of the Department \\ of Management and Financial and \\ Economic Security, \\ VASYLYSHYNA L., \\ Senior Lecturer, \\ Donetsk National Technical \\ University
}

У статті розглянуто особливості побудови ефективної організаційної моделі об'єднаних територіальних громад. Узагальнено нормативно-правові передумови створення нової територіальної структури. Визначено ключові критерії, які дочільно враховувати при побудові організаційної структури в сучасних умовах. Запропоновано основні структурні підрозділи майбутньої об'єднаної територіальної громади, виходячи зі стратегічного плану розвитку.

Ключові слова: територіальна структура, організачійна модель, об'єднана територіальна громада, критеріі, повноваження, відповідальність, органи самоврядування, стратегія.

В статье рассмотрены особенности построения эффективной организационной модели объединенных территориальных громад. Обобщены нормативно-правовые предпосылки создания новой территориальной структуры. Определены ключевые критерии, которые целесообразно учитывать при построении организационной структуры в современных условиях. Предложены основные структурные подразделения будущей объединенной территориальной общины, исходя из стратегического плана развития.

Ключевые слова: территориальная структура, организационная модель, объединенная территориальная громада, критерии, полномочия, ответственность, органы самоуправления, стратегия.

The features of building an effective organizational model of united territorial communities are considered in the article. The legal and legal prerequisites for the creation of a new territorial structure are generalized. The key criteria that should be considered when building an organizational structure in modern conditions are identified. The main structural units of the future united territorial community are proposed, based on the strategic development plan.

Keywords: territorial structure, organizational model, united territorial community, criteria, powers, responsibility, self-government bodies, strategy. 
Постановка проблеми. Процеси територіального реформування вимагають від органів місцевого самоврядування більшої самостійності в межах прийнятих на себе повноважень i, як наслідок, відповідальності за прийняті рішення. Соціально-економічний розвиток новоствореного територіального об'єднання - громади - знаходиться в прямій залежності від того, наскільки ії організаційна модель $є$ оптимальною, чи гармонійно побудовані відносини між структурними підрозділами та чи спрощує така структура управління життя пересічного громадянина. Від цього буде залежати досягнення стратегічних цілей та ефективне функціонування об’єднаної територіальної громади. Особливо гостро проблема відчувається в умовах дефіциту власних ресурсів, що вимагає зосередження на вдосконаленні організаційної моделі місцевих органів влади, яка включає в себе оптимізацію чисельності апарату управління, набуття унікальних компетентностей та підвищення кваліфікації управлінського персоналу, адаптація до нових умов територіального господарювання та мінливості зовнішніх факторів. Таким чином, на сьогоднішній день актуальність пошуку оптимальної організаційної моделі територіальної структури є беззаперечною.

Аналіз останніх досліджень $i$ публікацій. Теоретичну базу дослідження складають наукові праці організаційних теорій управління, науково-методичні розробки 3 питань формування та розвитку територіальних об'єднань, процесів децентралізації та державного реформування адміністративно-територіальних одиниць [1], [3] [6], [9].

Інформаційною базою $є$ розробки вітчизняних і зарубіжних вчених 3 питань проведення децентралізації в Україні та формування об'єднаних територіальних громад [2], [5]; Стратегічні напрямки розвитку потенційної майбутньої ОТГ [8]; нормативно-правові акти 3 регулювання територіальної реформи в Україні [4].

Meта cmammi. Головною метою даної роботи $\epsilon$ дослідження особливостей формування організаційної моделі об'єднаної територіальної громади.

Виклад основного матеріалу дослідження. Оптимальна організаційна модель територіальної структури є упорядкованою сукупністю елементів, які характеризуються відносною стійкістю взаємозв'язків та спроможні забезпечити іiі функціонування та соціально-економічний розвиток як єдиного цілого. 
Організаційна побудова нової територіальної структури призначена виконувати наступні завдання: створення умов для більш комфортного проживання мешканців; зменшення кількості депресивних населених пунктів; участь громадян у прийнятті життєво важливих рішень; підвищення відповідальності кожного члена громади.

Необхідність формування нових організаційних моделей управління територіальними структурами виникла в процесі територіального реформування, що розпочався у 2014 р. прийняттям Концепції реформування місцевого самоврядування та територіальної організації влади в Україні (01.04.2014р.), Законів України «Про співробітництво територіальних громад» (17.06.2014р.), «Про добровільне об’єднання територіальних громад» (05.02.2015 р.) та внесенням змін до Бюджетного і Податкового кодексів, що передбачали фінансову децентралізацію [9]. Саме фінансова децентралізація мала на меті надання більших можливостей органам місцевого самоврядування по втіленню програм розвитку відповідних територіальних об'єднань - громад.

Слід відмітити, що процес створення нових територіальних структур в процесі децентралізації на самому початку передбачав проходження двох етапів: добровільного та системного.

Схематично нормативно-правове забезпечення кожного 3 етапів представлено на рис. 1 .

Проте, як засвідчила практика, добровільне об'єднання зазнало значних труднощів. Запускаючи у 2014 р. реформу децентралізації, було анонсовано, що головним вигодонабувачем від реформи буде звичайний громадянин: надання адміністративних послуг спроститься завдяки створенню ЦНАП, можливостей вПлинути на стан інфраструктури стане більше через збільшення доходів місцевих бюджетів і більшої кількості повноважень при владі на місцях, а якість наданих медичних та освітніх послуг суттєво покращиться.

За попередні роки в ОТГ об'єдналися трохи більше 4,5 тисячі громад, що склало $42 \%$ від фінального плану зі створення громад на всій території країни. Так до кінця 2015 р. було створено тільки 159 об'єднаних територіальних громад (ОТГ), у 2016 р. їх вже налічувалося 366, у 2017 р. 665, у 2018 p. - 876 [5]. Найнижча активність створення ОТГ спостерігається у Донецькій і Луганській областях. У 2020 р. гострого вирішення потребує складне завдання: об'єднати в громади решту - a їх понад шість тисяч - сільських, селищних і міських рад. 


\section{ЕТАП 1. ДОБРОВІЛЬНИЙ<smiles>C1CCC1</smiles>

Передумови співробітництва:

Закон України «Про співробітництво територіальних громад»

Постанова КМУ «Про державну підтримку співробітництва територіальних громад» Наказ Мінрегіону «Про затвердження типових договорів співробітництва територіальних громад»<smiles>C1CCCC1</smiles>

\section{Передумови добровільного об'єднання:}

Закон України «Про добровільне об'єднання територіальних громад» Постанова КМУ «Про державну підтримку ОТГ»

\begin{tabular}{|c|c|c|}
\hline \multicolumn{3}{|c|}{$\begin{array}{l}\text { ЕТАП 2. СИСТЕМНИЙ } \\
\qquad Z\end{array}$} \\
\hline $\begin{array}{c}\text { Забезпечення основних реформ: } \\
\text { Закон України «Про місцеве } \\
\text { самоврядування» } \\
\text { Закон України «Про службу в } \\
\text { органах місцевого самоврядування» } \\
\text { Закон України «Про } \\
\text { адміністративно-територіальний } \\
\text { устрій» } \\
\text { Постанова КМУ «Про державний } \\
\text { реєстр адміністративно- } \\
\text { територіальних одиниць та } \\
\text { населених пунктів» } \\
\text { Наказ Мінрегіону «Методичні } \\
\text { рекомендації з моделювання } \\
\text { адміністративно-територіальних } \\
\text { одиниць» } \\
\text { Закон України «Про місцеві органи } \\
\text { виконавчої влади» } \\
\text { Постанова КМУ «Про структуру та } \\
\text { типові штати місцевих } \\
\text { держадміністрацій» } \\
\text { Постанова КМУ «Про типовий } \\
\text { регламент роботи місцевих } \\
\text { держадміністрацій» } \\
\text { Закон України «Про зміни до } \\
\text { Бюджетного Кодексу» } \\
\text { Закон України «Про зміни до } \\
\text { Податкового Кодексу» }\end{array}$ & $\begin{array}{c}\text { Забезпечення галузевих } \\
\text { змін: } \\
\text { Зміни до законодавства } \\
\text { про освіту } \\
\text { Зміни до законодавства } \\
\text { про охорону здоров’я } \\
\text { Закон України «Про Зміни } \\
\text { до Земельного Кодексу» } \\
\text { Закон України «Про зміни } \\
\text { до Водного Кодексу» } \\
\text { Зміни законодавства щодо } \\
\text { регулювання } \\
\text { містобудівної діяльності } \\
\text { Закон України «З } \\
\text { містобудівної діяльності» } \\
\text { Закон України «Про } \\
\text { столицю України - } \\
\text { м. Київ» }\end{array}$ & $\begin{array}{c}\text { Забезпечення участі } \\
\text { громадян: } \\
\text { Закон України «Про } \\
\text { вибори до органів } \\
\text { місцевого } \\
\text { самоврядування» } \\
\text { Закон України «Про } \\
\text { місцеві референдуми» } \\
\text { Закон України «Про } \\
\text { органи територіальної } \\
\text { самоорганізації } \\
\text { населення» } \\
\text { Постанова КМУ «Про } \\
\text { методичні } \\
\text { рекомендації щодо } \\
\text { діяльності органів } \\
\text { територіальної } \\
\text { самоорганізації } \\
\text { населення» } \\
\text { Закон України «Про } \\
\text { муніципальну } \\
\text { поліцію» } \\
\text { Закон України «Про } \\
\text { адміністративно- } \\
\text { територіальну } \\
\text { реформу» }\end{array}$ \\
\hline
\end{tabular}

Рис. 1. Нормативно-правове забезпечення створення нових територіальних структур [4] 
Слід зазначити, що для територій, на яких вже створені ОТГ, так і тих, що тільки планується об'єднати, важливими питанням є організаційна побудова територіальних органів управління. Іншими словами, важливо визначити правила, критерії, методи побудови оптимальної організаційної структури місцевого самоврядування. Жоден 3 наведених на рис. 1 нормативно-правових актів не регулює організаційну побудову органів місцевого самоврядування.

Створення ОТГ надає більше можливостей, повноважень та, як наслідок, більше відповідальності, тому структурувати орган управління так, як раніше, стає неможливим. Більшість ОТГ, які були створені протягом 2014-2015 pp., сформовані за принципом віддзеркалювання існуючих структур управління. Проте в реальних умовах функціонування відбулася трансформація первісних організаційних структур. ОТГ потребують самоорганізації, тому структури повинні бути гнучкими, відповідати сучасним умовам.

Вважається, що базою для побудови організаційної структури є стратегія розвитку ОТГ, тобто цільові орієнтири та завдання, які необхідно досягти в найближчий час перед членами громади, мають стати ключовими чинниками для побудови організаційної моделі ОТГ. Для різних громад структура буде відрізнятися. Не може бути уніфікованого підходу для міських, селищних чи сільських громад, так як кожна територія має свої потреби. ОТГ повинні зосереджуватися на стратегіях, повноваженнях i їх відповідальності, мають бути спроможними організувати себе для найбільш ефективної реалізації стратегічних орієнтирів.

В якості прикладу для побудови організаційної структури на основі стратегії розвитку розглянемо потенційну майбутню Новогродівську ОТГ, яку планується сформувати шляхом об’єднання Новогродівської міської ради та Миколаївської сільської ради. Стратегічним баченням ОТГ є екологічно безпечна громада, приваблива i відкрита до партнерства i співпраці [8].

В табл. 1 наведено SWOT-аналіз потенційної ОТГ.

На підставі SWOT-аналізу представляється можливим визначити стратегічні та оперативні цілі розвитку потенційної ОТГ (рис. 2). 
Таблиця 1

SWOT-аналіз потенційної майбутньої Новогродівської ОТГ

\section{Сильні сторони (Внутрішні} фактори)

Якості, ресурси, які можуть бути використані для досягнення мети

Вдале географічне та транспортне сполучення (автомобільні та залізничні шляхи)

Наявність природних ресурсів (корисні копалини)

Вільні людські ресурси (потенційна робоча сила)

Наявність соціальної інфраструктури (школи, дитячі садки, лікарня і т. п.)

Сприятливі кліматичні умови для ведення агробізнесу

Наявність вільних будівель для розміщення офісів

Наявність ринку вторинного житла

Наявність активних громадських організацій

\section{Слабкі сторони (Внутрішні фактори)}

Внутрішні недоліки і обмеження, що ставлять під загрозу досягнення цілей

Патерналістичні настрої населення

Низька якість комунікацій в сфері житловокомунального господарства

Використання забруднюючих повітря видів опалення (пічне опалення)

Незадовільний екологічний стан громади під впливом діяльності місцевих підприємств

Залежність від бюджетоутворюючих підприємств

Низька якість медичних та освітніх послуг

Погані дороги, тротуари, відсутність велодоріжок

Низький рівень громадської свідомості мешканців та їх залучення до активного суспільного життя

Недостатній рівень наявності кваліфікованої робочої сили

Відсутність довіри між владою і громадою, низький рівень комунікації

Близькість до бойових дій

Міграція працездатного населення

Криміналізація суспільства

\section{Можливості (Зовнішні фактори)}

Виграшні моменти, які створюються оточенням і могли би посприяти досягненню мети

\section{Створення ОТГ}

Залучення позабюджетного фінансування (досвід написання проектів, участь у різних програмах)

Співпраця суміжних громад

\section{Загрози (Зовнішні фактори)}

Зовнішні фактори, що можуть негативно вплинути на майбутню стратегію

\section{Військові дії}

Зарегульованість ведення бізнесу

Закриття містоутворюючих підприємств

Корупція

Часті зміни законодавства

Отже, виходячи із стратегічних орієнтирів в організаційній структурі потенційної майбутньої Новогродівської ОТГ представляється доцільним створення наступних функціональних відділів:

1. Відділ економічного розвитку та інвестицій (реалізація стратегічної цілі 1).

2. Відділ соціального захисту (часткова реалізація оперативної цілі 2.1).

3. Відділ охорони здоров’я (часткова реалізація оперативної цілі 2.1). 
4. Відділ освіти, спорту та культури (часткова реалізація оперативної цілі 2.1 та реалізація оперативної цілі 2.2).

5. Відділ житлово-комунального господарства, транспорту та благоустрою (реалізація оперативної цілі 2.3 та стратегічної цілі 3).

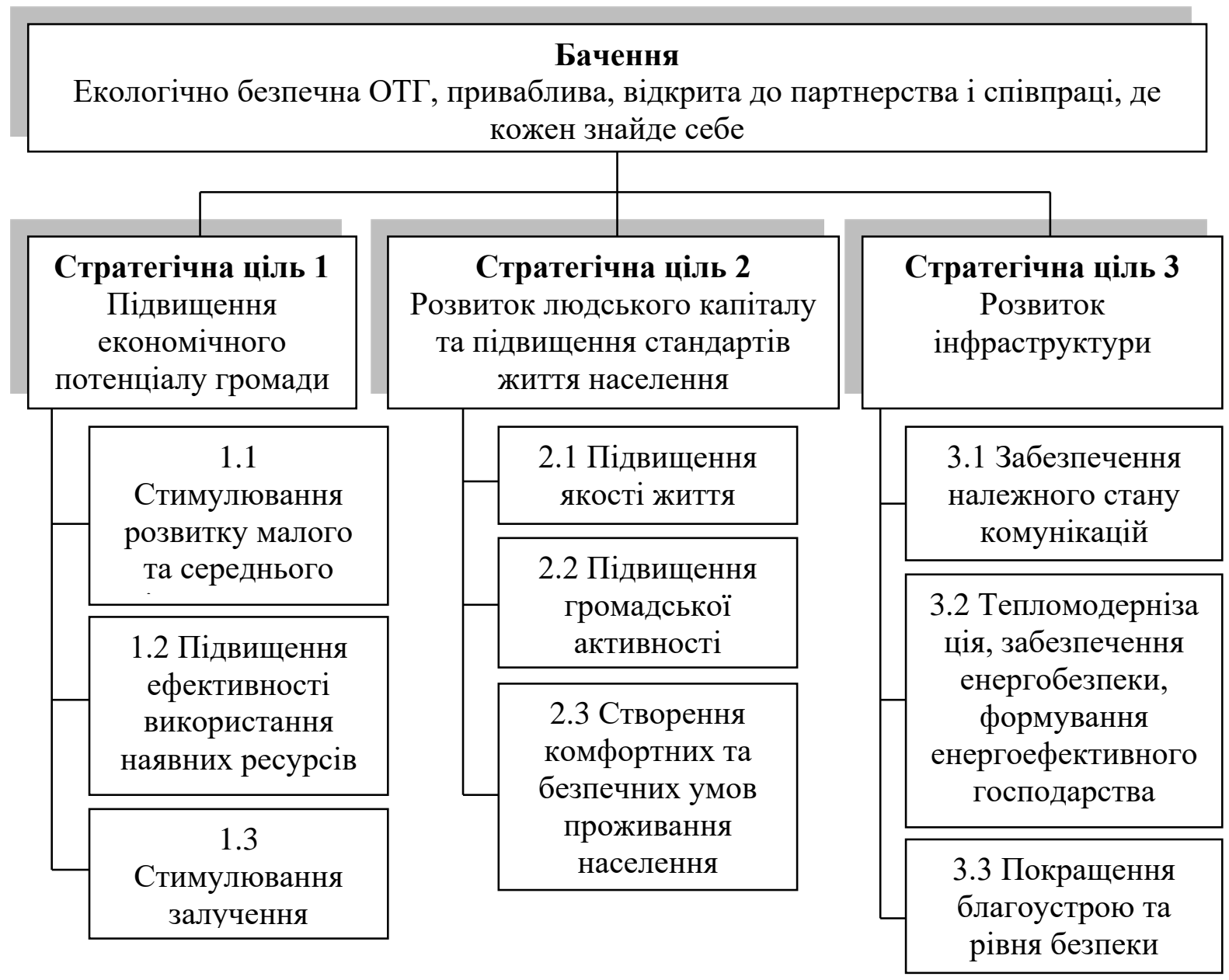

Рис. 2. Бачення, стратегічні та оперативні цілі майбутньої ОТГ

За іншими функціональними напрямками можна закріпити спеціаліста $з$ певними повноваженнями і відповідальністю.

При побудові організаційної структури ОТГ доцільно враховувати наступні критерії:

- структурованість повноважень і відповідальності (органи управління стають автономними, але більш відповідальними, організаційна структура повинна віддзеркалювати взяті на себе повноваження, не може бути повноваження без структурного підрозділу чи посадової особи, що реалізує дане повноваження); 
- гнучкість (організаційна структура ОТГ є гнучкою, тобто мінятися разом зі змінами в повноваженнях, але робота органу самоврядування не повинна припинятися);

- формалізація (необхідно прийняти положення про відділи, підрозділи, сектори, розроблені інструкції);

- фінансова спроможність (не більше 20\% на утримання організаційної структури ОТГ у власних доходах за розрахунками Мінрегіону);

- різні повноваження необхідно розглядати окремо (наприклад, якщо йде мова про освіту, то в міських та сільських ОТГ забезпечення буде різнитися суттєво).

Також існує думка, що організаційна структура ОТГ - це своєрідний «скелет», на який «надіваються» повноваження, які бажає, або може реалізувати орган місцевого самоврядування, а також спроможні люди. Це означає, що ефективна структура на одній території не може бути ефективною моделлю для іншої. Ефективність структури ОТР оцінюється якістю та доступністю надання різного роду послуг - публічних, житловокомунальних, освітніх і т. п. Тільки самі мешканці можуть дати оцінку ефективності організаційної структури ОТГ.

Досвід вже створених ОТГ свідчить, що для міських ОТГ повноваження було брати легше за рахунок більшої чисельності апарату управління. В сільських громадах проблемами стали як мала чисельність органу управління (від 3 до 7 посадових осіб), так і їх вузька спеціалізація (бухгалтерський облік, землевпорядкування), тому більшість послуг в таких утвореннях лягали на плечі секретаря або голови (освітні, соціальні, публічні). Спочатку відбулося злиття структур, а далі приймалися рішення щодо функцій кожного працівника в організаційній структурі. Практика об'єднання свідчить, що міські органи місцевого самоврядування приєднували невелику кількість органів, тому їх чисельність збільшилась лише в 1,5 рази. В той час, як в сільських та селищних ОТГ кількість органів самоврядування збільшилась в п’ять, а подекуди і в десять раз. Міські ОТГ вдосконалювали існуючі структурні підрозділи, в той час, як сільські ОТГ створювали все з нуля. Тому виникла проблема з залишком коштів для розвитку ОТГ після утримання іiі апарату управління. Ефективна структура управління не повинна збільшувати штат органів місцевого самоврядування, тому що кількість фахівців не $\epsilon$ передумовою якісного надання послуг. Важливо побудувати оптимальну структуру, що забезпечуватиме сталий розвиток території. $\mathcal{C}$ досить багато прикладів, 
коли ОТГ з чисельністю 20 тис. осіб обслуговує 60 посадових осіб органу місцевого самоврядування на досить високому рівні, а є ОТГ з чисельністю мешканців у $2-3$ рази менше $з$ тією ж чисельністю апарату управління.

Оргструктура ОТГ повинна формуватися відповідно до функцій, які планується виконувати. В таких умовах буде вважатися помилковим підхід, згідно $з$ яким відбудеться простий розподіл посад між існуючими органами місцевого самоврядування, або копіювання структури іншої територіальної структури. Головним організаційним ресурсом є людські ресурси, зокрема у сфері кадрового забезпечення апарату управління ОТГ. Спеціалістів якої категорії необхідно залучити на даній території в певному секторі для забезпечення повноваження (провідний спеціаліст, спеціаліст чи інспектор), потрібно вирішувати виходячи із поставлених цільових орієнтирів.

Підвищення ефективності організаційної структури ОТГ може відбутися шляхом зміни вертикальної структури на горизонтальну. За умови ефективної структури ОТГ мешканці повинні стати самоорганізованими. Це може бути виражено шляхом створення на добровільній основі об'єднань, спілок, так званих секторальних федерацій на певній території, які допомагатимуть органам місцевого самоврядування реалізовувати свої повноваження з надання якісних послуг населенню.

Разом 3 цим необхідно готувати, або підбирати спеціалістів 3 виконання певних функціональних повноважень, тому що прийде час, коли всі без винятку функції буде передано в ОТГ. Це, наприклад, стосується медичних послуг. В останній час набирають популярності мережеві взаємодії фахових спеціалістів, витісняючи традиційні методи підвищення кваліфікації. Підвищується роль консультування з окремих питань територіального управління. Такий підхід потребує значних ресурсів, насамперед фінансових, які не є метою, а важливим інструментом побудови ефективної ОТГ. Досвід Польщі - країни, що пройшла всі етапи територіальної реформи, вказує на те, що не завжди заможні територіальні об'єднання якісно виконують свої функції, дуже часто бідні повіти демонструють більш успішні результати.

Висновки $i$ перспективи подальших досліджень. Побудова організаційної структури ОТГ 3 орієнтацією на стратегічний план розвитку, на наш погляд, є більш доцільною, ніж побудова з орієнтацією на повноваження. Це пояснюється тим, що створення структурних підрозділів за повноваженнями носить механічний характер і може не 
привести до вдосконалення виконання відповідної функції. В той час, як стратегічний план містить місію, стратегічні цілі, оперативні цілі, завдання, окремі операції, що $\epsilon$ передумовою заздалегідь успішної діяльності органів місцевого самоврядування ОТГ.

Звичайно є приклади успішного функціонування ОТГ, в тому числі і сільських, які в першу чергу спроєктували організаційну структуру, прийняли статут, а лише потім перейшли до розробки стратегічних планів розвитку. При цьому слід вказати на важливу роль такої посади як проєктні менеджери громади, завдяки якому ОТГ залучалися до участі у грандах різного рівня.

Організаційна структура повинна бути побудована так, щоб ОТГ могли взяти на себе повноваження, які делегуються державою, в повному обсязі. $€$ такі ОТГ, які, наприклад, не виконують функції освіти на своїй території. Одразу виникає питання доцільності створення такої структури. I, навпаки, $є$ приклади сільських ОТГ, які надають всі можливі адміністративні, освітні, медичні та інші послуги, починаючи 3 нуля та постійно розширюючи їх спектр.

Таким чином, при побудові оптимальної організаційної моделі ОТГ матиме високий рівень відповідальності як перед державою у межах здійснення своєї діяльності відповідно до чинного законодавства, так i перед населенням шляхом проведення ефективної діяльності, визнаної більшістю громади.

\section{Лimepamypa:}

1. Гнидюк Н. Підходи до формування ефективних організаційних структур для об'єднаних територіальних громад. Київ, 2019. 26 с.

2. Децентралізація. URL: https://decentralization.gov.ua/.

3. Жуков А. П. Проектирование организационных структур исполнительно-распорядительных органов местного самоуправления как ресурс повышения эффективности муниципального управления в России. Вестник Университета. 2014. №7. С. 123-128.

4. Законодавчий портал Верховної Ради України. URL: http://zakon5.rada.gov.ua/laws/.

5. Офіс реформ Кабінету Міністрів України. Реформи. Децентралізація. URL: https://rdo.in.ua/direction/decentralizaciya.

6. Публічне врядування в Україні: стан, виклики та перспективи розвитку: матеріали щоріч. Всеукр. наук.-практ. конф. за міжнар. участю, присвяч. 100річчю держ. служби в Україні (Київ, 25 трав. 2018 р.): у 5 т. / за заг. ред. В. С. Куйбіди, М. М. Білинської, О. М. Петроє. Київ: НАДУ, 2018. Т.3. 128 с. 
7. Ричкіна Л. Модель розвитку територіальної громади із застосуванням інструментів проектного менеджменту (на прикладі конкретних територіальних громад). Ефективність державного управління: збірник наукових праџь. 2015. №45. С. 213-219.

8. Стратегічні напрями розвитку потенційної майбутньої ОТГ. Львів: Інститут лідерства та управління Українського католицького університету, 2019. $86 \mathrm{c}$.

9. Чаркіна А. О. Особливості концепції реформування місцевого самоврядування в сучасній Україні. Вісник Київського національного університету імені Тараса Шевченка. 2016. №1(5). С. 77-80.

\section{Referenses:}

1. Ghnydjuk N. Pidkhody do formuvannja efektyvnykh orghanizacijnykh struktur dlja ob'jednanykh terytorialjnykh ghromad. Kyjiv, 2019. $26 \mathrm{~s}$.

2. Decentralizacija. URL: https://decentralization.gov.ua/.

3. Zhukov A. P. Proektirovanie organizatsionnykh struktur ispolnitel'norasporyaditel'nykh organov mestnogo samoupravleniya kak resurs povysheniya effektivnosti munitsipal'nogo upravleniya v Rossii. Vestnik Universiteta. 2014. №7. S. 123-128.

4. Zakonodavchyj portal Verkhovnoji Rady Ukrajiny. URL: http://zakon5.rada.gov.ua/laws/.

5. Ofis reform Kabinetu Ministriv Ukrajiny. Reformy. Decentralizacija. URL: https://rdo.in.ua/direction/decentralizaciya.

6. Publichne vrjaduvannja v Ukrajini: stan, vyklyky ta perspektyvy rozvytku: materialy shhorich. Vseukr. nauk.-prakt. konf. za mizhnar. uchastju, prysvjach. 100richchju derzh. sluzhby v Ukrajini (Kyjiv, 25 trav. 2018 r.): u 5 t. / za zagh. red. V. S. Kujbidy, M. M. Bilynsjkoji, O. M. Petroje. Kyjiv: NADU, 2018. T.3. 128 s.

7. Rychkina L. Modelj rozvytku terytorialjnoji ghromady iz zastosuvannjam instrumentiv proektnogho menedzhmentu (na prykladi konkretnykh terytorialjnykh ghromad). Efektyvnistj derzhavnogho upravlinnja: zbirnyk naukovykh pracj. 2015. \#45. S. 213-219.

8. Strateghichni naprjamy rozvytku potencijnoji majbutnjoji OTGh. Ljviv: Instytut liderstva ta upravlinnja Ukrajinsjkogho katolycjkogho universytetu, 2019. $86 \mathrm{~s}$.

9. Charkina A. O. Osoblyvosti koncepciji reformuvannja miscevogho samovrjaduvannja $\mathrm{v}$ suchasnij Ukrajini. Visnyk Kyjivsjkogho nacionaljnogho universytetu imeni Tarasa Shevchenka. 2016. \#1(5). S. 77-80. 
The socio-economic development of the united territorial community depends directly on the optimal organizational model of governance, the harmony of relations between structural units.

The optimal organizational model of a territorial structure is an orderly set of elements characterized by relative stability of interconnections and capable of ensuring its functioning and socio-economic development as a whole.

Organizational construction of the new territorial structure is intended to fulfill the following tasks: creation of conditions for more comfortable living of the residents; reducing the number of depressed settlements; citizen participation in making vital decisions; increasing the responsibility of each community member.

To build the organizational structure, the basic foundation is the strategy of development of the united territorial communities, that is, the targets and goals that must be achieved in the near future, should become key factors in the construction of the organizational model. There can be no unified approach for urban, urban or rural communities, as each territory has its own specific characteristics and needs.

When building the organizational structure of a united territorial community, it is advisable to be guided by the following criteria: structured powers and responsibilities; flexibility; formalization; financial capacity; different powers need to be considered separately.

The effectiveness of the structure of the united territorial community is judged by the quality and accessibility of the provision of various services public, housing, education, etc. Only residents themselves can evaluate the effectiveness of the organizational structure.

Improving the organizational structure of a united territorial community can be achieved by changing the vertical structure to a horizontal structure. With the effective structure of a unified territorial community, residents should become self-organized. This can be expressed through the establishment, on a voluntary basis, of associations, unions, so-called sectoral federations in a certain territory, which will help local governments to exercise their authority to provide quality services to the population.

The organizational structure must be designed in such a way that the integrated territorial communities can fully assume the powers delegated by the state. 